\title{
A cure for AIDS: a matter of timing?
}

\author{
lart Luca Shytaj and Andrea Savarino*
}

\begin{abstract}
Despite the huge clinical success of antiretroviral therapy, several factors such as side effects, requirement of life-long adherence, high cost, incomplete access to therapies and development of drug resistance make the quest for an ultimate cure of HIV/AIDS a worldwide priority of biomedical research. In this respect, several sterilizing or functional cures have been reported in the last years in both non-human primates and humans. This review provides a summary of the main results achieved so far, outlining their strengths as well as their limitations. A synthetic interpretation of these results could be pivotal in order to develop an effective and widely available cure.
\end{abstract}

Keywords: Eradication, Functional cure, Reservoirs, Acute HIV infection, Stem cell transplantation, Vorinostat, Therapeutic vaccine, Auranofin, BSO

\section{Review}

\section{Introduction}

The quest of a cure for AIDS has been defined a "herculean task" [1], given the enormous complexities behind it and the numerous setbacks that have curbed early enthusiasms along the years. The ultimate goal of research for a cure is the complete eradication of the virus from the organism (i.e. a "sterilizing cure"), but a more feasible goal may be the achievement of spontaneous drugfree control of the infection without disease progression (i.e. a functional cure) [2]. The enormous difficulties that have been encountered in the quest of a cure for AIDS reside in the complex virus/host interplay that is a hallmark of this disease. Infection with HIV is initially characterized by a primary (acute) phase in which the virus is partially controlled by a robust immune response of the host [3]. Unfortunately, this immune response is not sufficient to eradicate the virus from the body, opening the way to the asymptomatic (chronic) phase. The chronic phase is characterized by an initial "steady state" between the virus and the immune system that is then slowly tilted in favor of the former, eventually leading to AIDS in the majority of the patients [4]. Treatment with antiretroviral drugs (ART) can reproducibly decrease viremia to levels below the limit of detection of the routine clinical assays and delays immune deterioration, but is not sufficient to tackle the viral reservoirs or to induce a strong immune response against the virus [5-7]. The viral reservoirs are formed early during acute infection [8] and are exceptionally stable sources of viral persistence $[6,9]$, harboring latent copies of integrated virus that are "invisible" to the immune system and unharmed by $\operatorname{ART}(5,6,9$, for a review on the latency mechanisms, see: [10]). Viral reservoirs can be of both myeloid and lymphoid lineage, allowing a widespread distribution to different compartments such as the central nervous system, the gut-associated lymphoid tissue and the reproductive tract [11]. At a cellular level, central and transitional memory $\mathrm{T}$-cells $\left(\mathrm{T}_{\mathrm{CM}}\right.$ and $\left.\mathrm{T}_{\mathrm{TM}}\right)$ were recently identified as a crucial source of viral persistence during therapy [12]. Additionally, macrophages are regarded as important contributors to this persistence, as well [13].

This review provides an outline of the therapeutic successes in the pathway towards a cure for AIDS. Our description is focused on the results that have so far been obtained in humans or SIV/SHIV infected macaques, which are, among the allowed animal models, those phylogenetically nearest to humans and most closely recapitulating the pathogenesis of human AIDS [14,15]. Recent reports have provided substantial data supporting the view that the path to a cure is a viable research avenue. These new data allow attempting a re-evaluation of the paradigms that have oriented cure-related research and addressing some of the questions that have so far been left unanswered.

\footnotetext{
* Correspondence: andrea.savarino@iss.it

Istituto Superiore di Sanità, Viale Regina Elena, 299, Rome 00161, Italy
} 


\section{Hit fast, hit hard}

Acute infection offers an ideal time window for effective therapeutic interventions [3]. A pioneering demonstration of the therapeutic potential of early treatment was the case report of spontaneous control of viral replication following treatment interruption in the first "Berlin Patient" [16] (not to be confused with Mr. Timothy Brown, the second "Berlin Patient", see next subchapter). This man was treated during acute infection with a nonstandard ART regimen (containing hydroxyurea) and subsequently underwent two structured treatment interruptions (STI). Eventually, after the second STI, the man displayed a long-lasting (19 months, until he was lost to follow-up) spontaneous control of viral load below the assay detection limit (500 copies of viral RNA/mL). Moreover, viral load control was accompanied by immune restoration, with $\mathrm{CD} 4$ counts and $\mathrm{CD} 4 / \mathrm{CD} 8$ ratio progressively increasing over time [16]. This striking result confirmed those of a previous study by Vila et al., employing a similar drug regimen and achieving as well a long-lasting post-therapy viral load control in two human subjects [17]. However, both studies were uncontrolled, and the two clinical cases described by Vila et al. were associated with high CD4 counts and low viral loads before treatment initiation [17]. A fully controlled animal study employing a therapy containing hydroxyurea administered sequentially in the form of multiple ART/STI cycles strengthened these case reports and showed that post-therapy viral load control could be induced in macaques acutely infected with the HIV homo$\log$ SIVmac251 [18]. Of note, in all these studies, apart from the early treatment initiation, hydroxyurea may have played a role in the post-therapy viral load control obtained. Hydroxyurea exerts a cytostatic effect by inhibiting the activity of the ribonucleotide reductase enzyme, thus halting the cell cycle at the G1 phase [19]. This effect may hamper viral reservoir maintenance/expansion in $\mathrm{T}_{\mathrm{CM}}$ and $\mathrm{T}_{\mathrm{TM}}$ cells that mainly relies on antigen-driven and homeostatic proliferation respectively [12]. Despite these promising results, combinations of hydroxyurea and antiretroviral drugs displayed in some instances high pancreatic and hepatic toxicity $[20,21]$ and consequently hydroxyurea is not recommended for routine treatment of HIV infection, although there is still ongoing research on this topic [22].

Another uncommon ART regimen administered during early infection yielded promising results in a recent study conducted in macaques infected with different SIV/SHIV strains [23]. In some of these animals, a prolonged (more than 8 years) tenofovir monotherapy proved able to induce a spontaneous control of the infection following the final treatment withdrawal [23]. Apart from the early treatment initiation, this result may be due to an effect of tenofovir in selecting suboptimal drug resistance mutations, and the result may also have been contributed by the additional interventions to which the macaques were subjected during follow-up (temporary depletion of $\mathrm{CD}^{+}$cells and treatment at viral rebound).

Treatment during acute infection has provided some amount of clinical success also with more traditional ART regimens [24-30]. News such as the case report of the cure of an ostensibly $\mathrm{HIV}^{+}$baby treated in the very early phase of the disease [30] and, more importantly, the results of the ANRS VISCONTI study [29] have been hailed with widespread enthusiasm. Of particular note, up to $\approx 15 \%$ of the early treated individuals have been shown to display spontaneous control of viremia following STI [27]. However, the rate of post-therapy control following ART administration during the acute phase may be lower $(\approx 5 \%)$ according to another report [28]. Moreover, no definite timing and drug composition has been proven to reproducibly induce post-therapy control even in a minority of patients, and several studies have failed to induce any significant reduction in the post-therapy viral set point following treatment during acute infection [31-33].

Despite these mixed results, the data available indicate that ART administration during acute infection can induce, in a minority of cases, a post-therapy control of the infection which is independent from known favorable genetic backgrounds [29] (Figure 1). Several hypotheses have been postulated to explain the enhanced efficacy of ART treatment during primary infection. The most frequently cited explanations are: 1) the preservation of an efficient immune response $[34,35], 2)$ the induction of a "self-vaccination" after multiple STIs [16,18], and 3) the impairment of viral reservoir formation [27,29,36-38]. A reduced viral reservoir size does not per se guarantee successful ART withdrawal [39], but is, even in the most conservative scenario, a promising platform in the quest of a cure. The overwhelming majority of $\mathrm{HIV}^{+}$individuals, however, are diagnosed during the chronic phase of the infection, and a large body of evidence shows that STI protocols (even in the form of short "drug holidays") are not effective in improving the course of the disease once the chronic phase is established ([40-42], reviewed in: [43]).

\section{Hit later, hit harder}

The mainstream approach to purge the viral reservoirs during chronic infection is a multi-step "shock and kill" therapy [44]. During the "shock" phase, the latent virus harbored in the reservoirs is expected to be pharmacologically reactivated and prompted to resume productive infection. During the"kill" phase, the newly produced virions would be blocked by ART, while the HIV-infected cells are expected to be eliminated by viral cytopathogenicity, or recognized and killed by the immune system. A plethora of compounds have been put forward as candidates to induce the "shock" phase (recently reviewed in: 


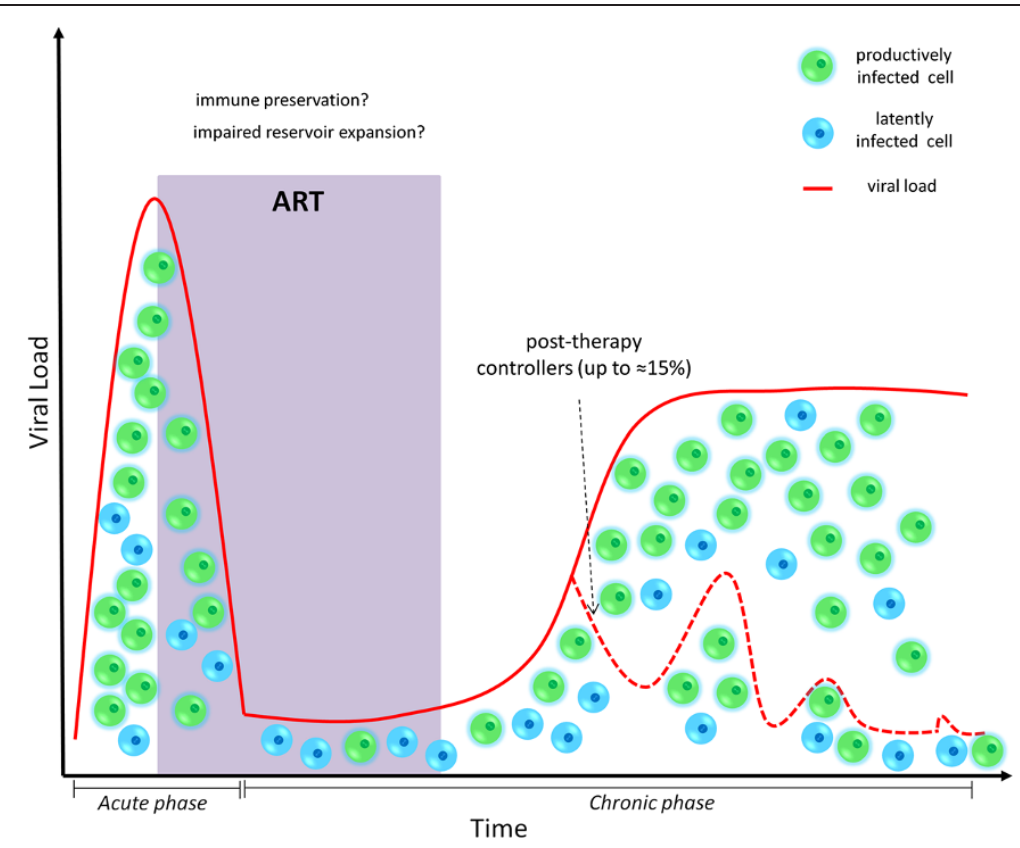

Figure 1 ART administration during acute infection results in spontaneous control of viral load in a minority of individuals following therapy suspension. The dotted line depicts representative viral load dynamics of patients controlling the infection following ART withdrawal, as compared to non controllers (solid line). The upper limit of the percentage of controllers is taken from [27]).

[45,46]). Among these, the most thoroughly investigated are histone deacetylase inhibitors (HDACl's). Several HDACI's (e.g. valproic acid, vorinostat, panobinostat) have been tested or are currently under investigation in both pre-clinical studies and clinical trials (reviewed in: [47]). Vorinostat [i.e. suberoylanilide hydroxamic acid (SAHA)] was recently reported to have a moderate latency disrupting effect in a group of patients previously selected for the responsiveness of their resting $\mathrm{CD}^{+}$memory T-cells to treatment with this drug in vitro [48]. However, preliminary data do not show significant effects of vorinostat on viral reservoir size $[49,50]$, while no data on post-therapy viral dynamics are available so far. Moreover, treatment with combined ART/vorinostat regimens on SIVmacinfected macaques led to mixed or disappointing results [51,52]. More data on the in-vivo effects of vorinostat will be available from the two ongoing clinical trials investigating the effects of this drug on individuals under ART (NCT01319383, NCT01365065). For the remaining HDACl's only data obtained from cell cultures are available at present [53-55], although panobinostat is currently under investigation in a Phase I/II clinical trial (NCT01680094).

Another approach aimed at HIV reactivation from latency involves the use of cytokines (reviewed in [56]). In particular, the use of IL-7 in combination with ART intensification is currently being investigated (NCT01019551). Unfortunately, in two recent clinical trials, the addition of IL-7 to standard ART protocols did not result in viral reactivation from latency [57], and increased the size of the viral reservoir [58], in line with the well-known effects of this cytokine, favoring homeostatic proliferation of $\mathrm{T}_{\mathrm{CM}}$ and $\mathrm{T}_{\mathrm{TM}}$ cells $[12,58,59]$.

Despite the enormous efforts that have been put in the study of HIV reactivating HDACI's and cytokines, the most promising results so far obtained in the quest of a cure for AIDS are not derived from these approaches. The most astonishing result in the field to date, and the first proof of concept for the feasibility of a sterilizing cure during chronic HIV infection, is the case report of the treatment of Mr. Timothy Brown, the aforementioned second "Berlin Patient" [60,61]. Apart from being chronically infected with HIV, this man was diagnosed with acute myeloid leukemia and consequently treated with an aggressive combination of ablative chemotherapy/radiotherapy, immune suppression through drugs and allogeneic stem cell transplantation. Importantly, the donor selected for the transplantation was homozygous for the $\Delta 32$ deletion of the CCR5 gene [60]. This gene encodes for the main coreceptor employed by HIV for entry into cells, and individuals homozygous for the $\Delta 32$ deletion (about $1 \%$ of the caucasian population) are protected from HIV infection [62]. Following stem cell transplantation, Mr. Brown stopped taking antiretroviral drugs, and has remained offART since then, with no signs of disease progression $[60,61]$. Of note, in spite of an extensive sampling throughout the years, most of the analyses have failed to detect HIV RNA or DNA in blood and tissues, and the HIVspecific antibody titers have steadily decreased over time, 
thus hinting that a complete eradication may have been achieved $[61,63]$. Despite the enormous excitement generated by the news of this cure, the scarcity of HLA-DRcompatible CCR5 $\triangle 32$ donors makes it very difficult to replicate the whole experiment. Consequently, several attempts have been made to isolate the contribution of each of the different therapy components. Allogeneic bone marrow transplantation had been employed for treatment of HIV since the first years of the epidemics (reviewed in [64]) and had been even advocated as a possible curing strategy [65]. The most visible difference between these early attempts and the treatment of Timothy Brown is the favorable genetic background of the cells received by the latter, bearing the homozygous CCR5 $\triangle 32$ deletion. Thus, it is not surprising that many investigators have used this observation as a starting point for further studies. In this regard, a gene therapy approach aimed at disrupting the CCR5 gene (virtually recreating the $\triangle 32$ deletion) is currently under investigation in clinical trials (NCT01252641, NCT00842634). In these studies, the disruption of CCR5 is performed employing zinc finger nucleases in previously isolated autologous cells that are afterwards re-transplanted in the host. The preliminary results released so far do not allow drawing a definite conclusion on post-therapy viral load dynamics, which seem to be quite variable among study subjects, although post-therapy viral load containment may have been achieved in a small subset of individuals that were heterozygous for CCR5 $\triangle 32$ at baseline [66]. Anyway, the zinc finger treated $\mathrm{CD} 4^{+} \mathrm{T}$-cells have been shown to be able to persist in the organism at least one year after the transplant and have had an enhancing effect on CD4 counts in immunologic non-responders [67].

On the other hand, recent data indicate that allogeneic stem cell transplantation may possibly lead to a cure also in the absence of the CCR5 $\triangle 32$ mutation. This is suggested by the outcome of the treatment of two $\mathrm{HIV}^{+}$individuals (the "Boston patients") that had received an allogeneic transplantation of stem cells from CCR5 wild-type donors. After transplantation, while still receiving ART, these individuals displayed a reduction of viral DNA in peripheral blood to undetectable levels [68]. Further investigation proved that viral DNA could not be detected with large scale analysis in PBMCs and in rectal tissue, and thus STI was attempted in both patients [69]. Following ART interruption, no viral rebound was observed, and, despite the relatively short follow-up, the data available suggest that a cure may have been achieved [69]. An important element of the strategy employed for treating the "Boston patients" may have been the long-term ART maintenance following transplantation which may have blocked viral reseeding before the establishment of a full donor chimerism. This aspect differentiates the "Boston patients" from the second "Berlin patient" in which ART was discontinued from the day of transplantation and viral reseeding was likely hampered by the CCR5 $\triangle 32$ mutation of the transplanted cells. On the other hand, a common feature between these case reports is that the "Berlin patient" and the two "Boston patients" were all heterozygous for CCR5 $\Delta 32$ before transplantation [60,68] (see Figure 2). Although their blood cells were fully replaced afterwards (by homozygous CCR5 $\triangle 32$ cells in the "Berlin patient" and by wild type CCR5 cells in the "Boston patients"), it cannot so far be excluded that their original CCR $\triangle 32$ heterozygous status may have played a role in the clinical outcome. It is known that heterozygosity for CCR 532 is associated with slower disease progression [62,70] and the results of a recent study conducted in non-human primates suggest that CCR5 expression levels may be associated with the size of the viral reservoir [71]. Despite the necessity of conducting further studies on this topic, the high treatmentrelated mortality of allogeneic transplant [72] hampers the use of this technique as an HIV curing strategy, unless salvage therapies are required due to life-threatening comorbidities. On the whole, the studies hereto reviewed support the hypothesis that decreasing the viral reservoir size through drugs, coupled to immune system renovation, may be a key to the achievement of a cure.

\section{Turning back time}

From the aforementioned studies, it is evident that the therapies that have resulted in a cure during the chronic phase of the infection bear a much higher degree of risk as compared to the strategies adopted in the acute phase. Thus, the possibility of inducing an acute infection-like scenario in an advanced stage of the disease may represent a unique option to open a new window of opportunity for the therapeutic interventions adopted during the acute phase. A good candidate for this strategy is the gold-based compound auranofin [52] which has been employed for many years in treatment of rheumatoid arthritis [73]. Our group has recently shown the potential of auranofin to act as an anti-reservoir compound in vivo when administered to chronically-SIVmac251 infected macaques [52]. Of note, auranofin is able to preferentially induce differentiation/cell death of the memory $\mathrm{T}$-cell compartment including the $\mathrm{T}_{\mathrm{CM}}$ and $\mathrm{T}_{\mathrm{TM}} \mathrm{CD} 4^{+}$cells which encompass the main viral reservoir [52] (for a schematic representation of the mechanism of action of auranofin, see Figure 3). Beside its anti-reservoir effect, the addition of auranofin to ART was able to prompt a drastic modification of the post-therapy viral load dynamics in chronically SIVmac251infected macaques [52,74]. Following treatment interruption, the macaques that had received the ART/auranofin combination displayed a sharp viral load rebound reminiscent of an acute infection peak which was in turn accompanied by an increase in specific immune responses in accordance with the typical acute infection scenario [3,74]. From a therapeutic perspective, treatment with ART/ 

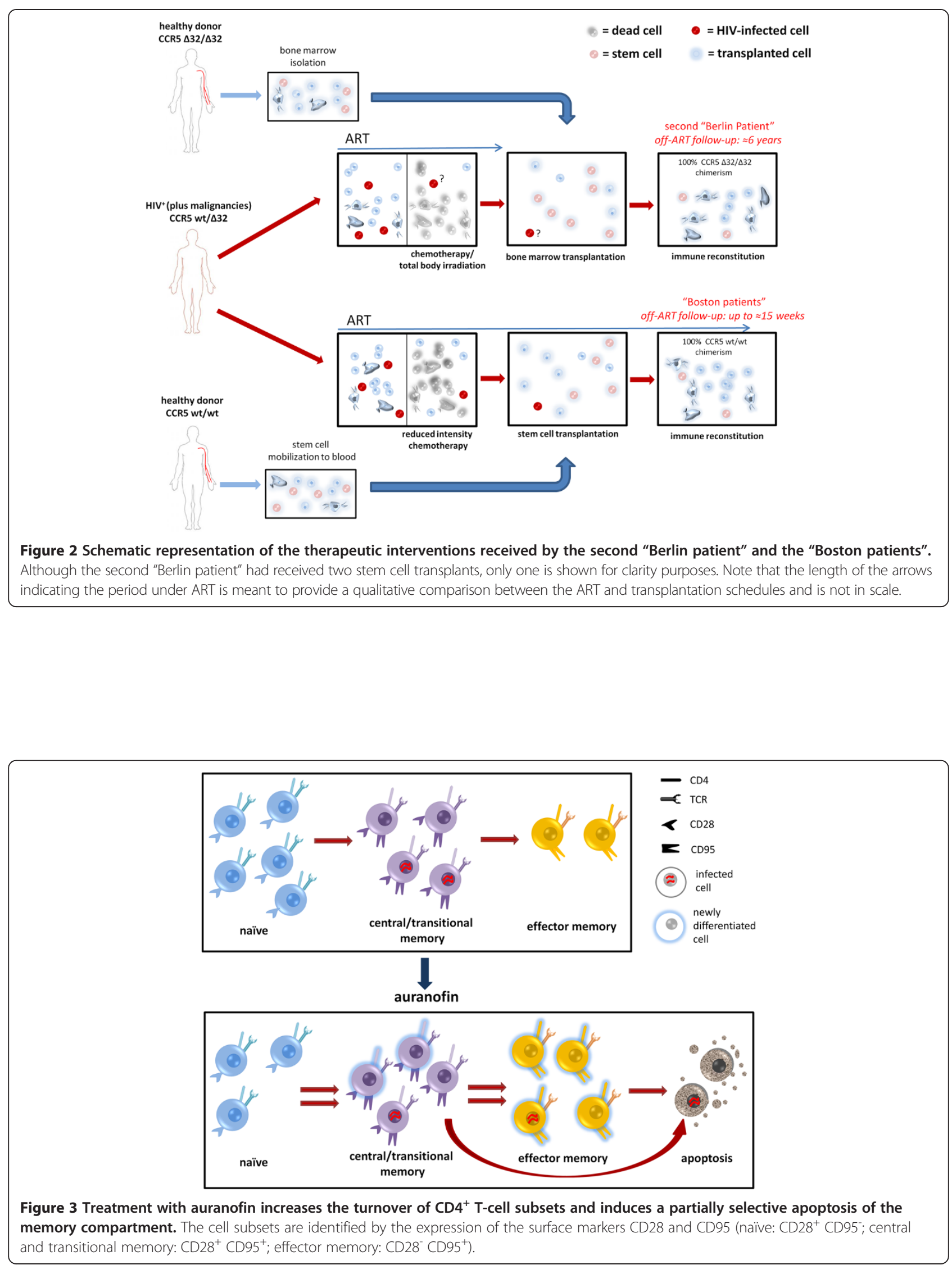
auranofin induced a reduction in post-therapy viral load set point $\left(\approx 1 \log _{10}\right.$ viral RNA copies/mL of plasma) [52] and, importantly, treatment during the acute infection-like viral rebound showed the potential to mimic the aforementioned effects of early ART administration [74]. Indeed a short cycle of ART during the acute infection-like peak induced a further reduction in post-therapy viral load set-point [74] and, despite being attempted in a low number of macaques $(\mathrm{n}=2)$, would prove effective in the long-term follow-up [74]. The viral load control induced with this therapeutic protocol may have been contributed to by the previous reservoir reduction prompted by auranofin and by the use of an ART regimen containing maraviroc, which, by blocking CCR5, may inhibit antigen-driven proliferation of the viral reservoir [74]. Although the mechanism behind the drastic modification of the viral rebound pattern induced by auranofin remains partially unclear, its effects on the macaque AIDS model suggest that this drug may offer an attractive possibility of successfully applying, to the chronic phase of the infection, strategies that would have been effective only in the early stages.

Immune enhancement: rejuvenating the immune system? Enormous efforts have been put in the development of strategies able to boost antibody and/or cell-mediated immune responses against HIV (reviewed in [75]). The curative potential of broad and robust cell-mediated immune responses, in particular by $\mathrm{CD}^{+} \mathrm{T}$-cells, is suggested by the association of such responses with better disease progression resulting in spontaneous drug-free control of viral load in a minority of individuals [76-79]. Thus, drugs able to bolster immunity against HIV-infected cells could represent an ideal tool for prompting, or supporting, a spontaneous control of the infection [75]. A promising compound for enhancing cell-mediated immune responses against HIV may be buthionine sulfoximine (BSO), a glutathionedepleting agent previously tested for cancer treatment in phase I clinical trials [80]. We recently showed that the addition of BSO to the aforementioned ART/auranofin combination is able to promote a significant and longlasting enhancement of specific immune responses directed against SIVmac Gag [81]. Boosting immunity against Gag is an attractive achievement because several studies have shown that strong anti-Gag immune responses are associated with low viral loads and high CD4 counts both in macaques and humans [82-86]. Moreover, the results of a recent study suggest that $\mathrm{CD} 8^{+} \mathrm{T}$-cells may reduce the viral reservoir by recognizing Gag antigens produced by latently infected resting $\mathrm{CD}^{+}{ }^{+} \mathrm{T}$-cells [87]. In accordance with these studies, enhancement of the immune responses against Gag following suspension of treatment with ART/auranofin/BSO was associated with the obtainment of a functional cure-like condition in a study conducted on a small number of chronically SIVmac251infected macaques [81].

Partially similar results were obtained using a therapeutic vaccine based on dendritic cells pulsed with whole inactivated virus [88-91]. This vaccine proved able to achieve drug-free control of viral load in a subset of chronically SIVmac251-infected macaques [88] and to induce a reduction of viral load, although moderate, in ART-naïve $\mathrm{HIV}^{+}$ subjects $[89,90]$. Moreover, coupling the vaccine administration to ART induced a reduction in post-therapy viral load set point in some individuals [91]. Of note, the highest viral load reductions observed in ART-naïve subjects were associated with high numbers of Gag-specific $\mathrm{CD}^{+}$ T-cells [89].

A proof-of-concept that strong $\mathrm{CD}^{+}$(in particular $\mathrm{T}_{\mathrm{EM}}$ )-mediated immune responses can even lead to viral eradication was recently furnished by a preventive vaccine study conducted on macaques challenged with SIVmac239 [92]. Despite all vaccinated macaques becoming infected following multiple challenges with the virus [93], about half of them proved able to spontaneously control the infection and, strikingly, to get rid of the virus completely in the long run [92]. Interestingly, an involvement of $\mathrm{T}_{\mathrm{EM}}$ cells was also shown, by multiple correlation analysis, in the effects of the auranofin-based therapeutic approach [52].

On the other hand, antibody-mediated immune responses have also proven the ability of inducing posttherapy viral load control $[94,95]$. In particular, in the recent study of Barouch et al., a cohort of SHIV(env)-infected macaques was treated with wide spectrum neutralizing antibodies [95]. This treatment produced a functional cure in those macaques starting from viral loads of less than 3.5 $\log _{10}$ viral RNA copies/mL of plasma [95]. Of note, this experiment provides an artificial substitution of a "nonfunctional" immune system with a surrogate functional immunity, i.e. the passive antibody transfer. The capability of adoptive antibody transfer to induce a functional cure only in those macaques displaying low baseline viral set points, supports the view that a limited viral reservoir should accompany the immune system renovation.

Finally, also the effects of transplantation strategies on viral load control may be associated with enhancement of immune responses. A study by Villinger et al. conducted in chronically SIVmac239-infected macaques showed that adoptive transfer of activated autologous $\mathrm{CD}^{+}$T-cells may result in spontaneous post-therapy control of the infection [96]. This approach can hardly be employed in humans since it requires cells isolated before the infection, but it suggests that renovation of the immune system is important for obtaining effective immune responses [96]. Of note, autologous stem cell transplantation did not result in a cure of $\mathrm{HIV}^{+}$individuals [97], suggesting that cells isolated following infection may not be apt to prompt immune enhancement. Instead, the likely cures observed 
Table 1 Summary of the main characteristics of the therapeutic strategies described in this review

\begin{tabular}{|c|c|c|c|c|}
\hline & Notable Results & Stage & Safety & Scalability \\
\hline ART during acute infection & $\begin{array}{l}\text { Long-term post-therapy viral load control in a } \\
\text { minority of individuals }[16,17,23-30] \text {. }\end{array}$ & Clinical/pre-clinical & High & $\begin{array}{l}\text { Low (few patients are detected } \\
\quad \mathrm{HIV}^{+} \text {at acute infection) }\end{array}$ \\
\hline Viral reactivation with $\mathrm{HDACl}^{\prime} \mathrm{s}$ & $\begin{array}{l}\text { Possible disruption of latency [48,49,53-55]. } \\
\text { No viral reservoir reduction [49]. }\end{array}$ & Clinical/pre-clinical & Medium & High \\
\hline Viral reactivation with cytokines & $\begin{array}{l}\text { IL-7 might disrupt latency but replenishes } \\
\text { the viral reservoir [57-59]. }\end{array}$ & Clinical & Medium & Medium/high \\
\hline $\begin{array}{l}\text { Gene therapy for disruption } \\
\text { of } C C R 5\end{array}$ & $\begin{array}{l}\text { Mixed impact on viral load (depending on the genetic } \\
\text { background) [66]. Possible immunologic improvement [67]. }\end{array}$ & Clinical & Medium (long-term effects unknown) & Very low \\
\hline Allogeneic stem cell transplant & $\begin{array}{l}\text { Likely sterilizing cures in the second "Berlin Patient" } \\
{[60,61,63] \text { and in the "Boston Patients" }[68,69] \text {. }}\end{array}$ & Clinical & Very low & Very low \\
\hline Addition of auranofin and BSO to ART & $\begin{array}{l}\text { Long-term post-therapy control in chronically } \\
\text { SIVmac251 infected macaques }[74,81] \text {. }\end{array}$ & Late pre-clinical & $\begin{array}{l}\text { Medium/high (good safety profile } \\
\text { for individual drugs in humans) }\end{array}$ & High \\
\hline $\begin{array}{l}\text { Therapeutic vaccine with whole } \\
\text { virus-pulsed dendritic cells }\end{array}$ & $\begin{array}{l}\text { Post-therapy viral load control in a subset of macaques [88]. } \\
\text { Viral load and viral load set-point reduction in a subset of } \\
\text { ART-naïve }[89,90] \text { and ART-treated patients [91], respectively }\end{array}$ & Clinical & High & Medium \\
\hline $\begin{array}{l}\text { Administration of broadly } \\
\text { neutralizing antibody/ies }\end{array}$ & $\begin{array}{l}\text { Long-term post-therapy control in chronically } \\
\text { SHIV(env) infected macaques starting from } \\
\text { low viral loads [95] }\end{array}$ & Late pre-clinical & High & High \\
\hline
\end{tabular}

In square brackets are the references describing the main results for each strategy. 
following allogeneic transplantation in the "Boston patients" [69] may have been induced or facilitated by the strong immune responses resulting from graft versus host disease, exacerbated by a partial HLA donor/receiver mismatch in one of the two patients, which may have played a critical role for the elimination of the viral reservoirs [68].

\section{Conclusions}

The studies reviewed herein indicate that curing, and even eradicating primate lentiviruses, including HIV-1, could be possible, at least in certain cases (see Table 1). However, it is important to point out that the majority of the "functional" cures that have so far been reported have been obtained during the acute phase or a short time thereafter, i.e. at a time in which the viral reservoir and the immune damage are still limited. The design of future therapeutic strategies should address the chronic phase of the disease, affecting the large majority of the $\mathrm{HIV}^{+}$individuals. The most successful approaches tested so far, though still preliminary and/or based on a small number of cases, strongly suggest that the path to a cure involves two key players: the viral reservoir and the immune system. In the typical scenario of chronic infection with an average/large viral reservoir and an impaired immune system, some of the approaches that have been successful showed the ability to target both the viral reservoir and the immune system through gradual (auranofin) or abrupt (chemotherapy/allogeneic transplant) immune system renovation, followed by enhanced immune responses either against conserved viral antigens (auranofin + BSO) or the host's infected cells (graft versus host disease). In this regard, further studies, fully controlled and with larger number of subjects, will be required to assess the curative potential of the aforementioned strategies. The ultimate goal will be to obtain with scalable drug combinations, the cure that has been induced with more aggressive approaches.

\section{Abbreviations}

ART: Antiretroviral therapy; STI: Structured treatment interruption;

HDACl: Histone deacetylase inhibitor; SIV: Simian immunodeficiency virus; SHIV: Simian/human immunodeficiency virus; BSO: Buthionine sulfoximine; $\mathrm{T}_{\mathrm{CM}}:$ T central memory; $\mathrm{T}_{\mathrm{TM}}: \mathrm{T}_{\mathrm{T}}$ transitional memory; $\mathrm{T}_{\mathrm{EM}}: \mathrm{T}^{\mathrm{T}}$ effector memory.

\section{Competing interests}

The Istituto Superiore di Sanità has requested patent rights on the use of the auranofin/BSO combination for treatment of HIV/AIDS.

\section{Authors' contributions}

AS and ILS developed the overall theory disclosed in this review, analyzed the literature and drafted the manuscript. ILS drew the original figures. All authors read and approved the final manuscript.

\section{Acknowledgements \\ The authors are thankful to Dr. Marco Sgarbanti for critically reading the manuscript and for providing helpful suggestions.}

Received: 13 October 2013 Accepted: 12 November 2013

Published: 22 November 2013

\section{References}

1. Margolis DM: Eradication therapies for HIV infection: time to begin again. AIDS Res Hum Retroviruses 2011, 27(4):347-353. doi: 10.1089/aid.2011.0017. Review.

2. Trono D, Van Lint C, Rouzioux C, Verdin E, Barré-Sinoussi F, Chun TW, Chomont N: HIV persistence and the prospect of long-term drug-free remissions for HIV-infected individuals. Science 2010, 329(5988):174-180. doi: 10.1126/science.1191047. Review.

3. Kahn JO, Walker BD: Acute human immunodeficiency virus type 1 infection. N Engl J Med 1998, 339(1):33-39. Review.

4. Pantaleo G, Fauci AS: Immunopathogenesis of HIV infection. Annu Rev Microbiol 1996, 50:825-854. Review.

5. Finzi D, Hermankova M, Pierson T, Carruth LM, Buck C, Chaisson RE, Quinn TC, Chadwick K, Margolick J, Brookmeyer R, Gallant J, Markowitz M, Ho DD, Richman DD, Siliciano RF: Identification of a reservoir for HIV-1 in patients on highly active antiretroviral therapy. Science 1997, 278(5341):1295-1300.

6. Finzi D, Blankson J, Siliciano JD, Margolick JB, Chadwick K, Pierson T, Smith K, Lisziewicz J, Lori F, Flexner C, Quinn TC, Chaisson RE, Rosenberg E, Walker B, Gange S, Gallant J, Siliciano RF: Latent infection of $\mathrm{CD}^{+} \mathrm{T}$ cells provides a mechanism for lifelong persistence of HIV-1, even in patients on effective combination therapy. Nat Med 1999, 5(5):512-517.

7. Migueles SA, Weeks KA, Nou E, Berkley AM, Rood JE, Osborne CM, Hallahan CW, Cogliano-Shutta NA, Metcalf JA, McLaughlin M, Kwan R, Mican JM, Davey RT Jr, Connors M: Defective human immunodeficiency virus-specific CD8+ T-cell polyfunctionality, proliferation, and cytotoxicity are not restored by antiretroviral therapy. J Virol 2009, 83(22):11876-11889. doi: 10.1128/JVI.01153-09.

8. Chun TW, Engel D, Berrey MM, Shea T, Corey L, Fauci AS: Early establishment of a pool of latently infected, resting CD4(+) T cells during primary HIV-1 infection. Proc Natl Acad Sci U S A 1998, 95(15):8869-8873.

9. Siliciano JD, Kajdas J, Finzi D, Quinn TC, Chadwick K, Margolick JB, Kovacs C, Gange SJ, Siliciano RF: Long-term follow-up studies confirm the stability of the latent reservoir for HIV-1 in resting $\mathrm{CD}^{+}{ }^{+}$T cells. Nat Med 2003, 9(6):727-728.

10. Donahue DA, Wainberg MA: Cellular and molecular mechanisms involved in the establishment of HIV-1 latency. Retrovirology 2013, 10:11. doi: 10.1186/1742-4690-10-11. Review.

11. Blankson JN, Persaud D, Siliciano RF: The challenge of viral reservoirs in HIV-1 infection. Annu Rev Med 2002, 53:557-593. Review.

12. Chomont N, El-Far M, Ancuta P, Trautmann L, Procopio FA, Yassine-Diab B, Boucher G, Boulassel MR, Ghattas G, Brenchley JM, Schacker TW, Hill BJ, Douek DC, Routy JP, Haddad EK, Sékaly RP: HIV reservoir size and persistence are driven by T cell survival and homeostatic proliferation. Nat Med 2009, 15(8):893-900. doi: 10.1038/nm.1972.

13. Koppensteiner $H$, Brack-Werner $\mathrm{R}$, Schindler M: Macrophages and their relevance in human immunodeficiency virus type I infection. Retrovirology 2012, 9:82. doi: 10.1186/1742-4690-9-82.

14. Perelman $P$, Johnson WE, Roos $C$, Seuánez HN, Horvath JE, Moreira MA, Kessing B, Pontius J, Roelke M, Rumpler Y, Schneider MP, Silva A, O'Brien SJ, Pecon-Slattery J: A molecular phylogeny of living primates. PLoS Genet 2011, 7(3):e1001342. doi: 10.1371/journal.pgen.1001342.

15. Del Prete GQ, Lifson JD: Considerations in the development of nonhuman primate models of combination antiretroviral therapy for studies of AIDS virus suppression, residual virus, and curative strategies. Curr Opin HIV AIDS 2013, 8(4):262-272. doi: 10.1097/COH.0b013e328361cf40.

16. Lisziewicz J, Rosenberg E, Lieberman J, Jessen H, Lopalco L, Siliciano R, Walker B, Lori F: Control of HIV despite the discontinuation of antiretroviral therapy. N Engl J Med 1999, 340(21):1683-1684.

17. Vila J, Nugier F, Barguès $G$, Vallet $T$, Peyramond $D$, Hamedi-Sangsari F, Seigneurin JM: Absence of viral rebound after treatment of HIV-infected patients with didanosine and hydroxycarbamide. Lancet 1997, 350(9078):635-636

18. Lori F, Lewis MG, Xu J, Varga G, Zinn DE Jr, Crabbs C, Wagner W, Greenhouse J, Silvera P, Yalley-Ogunro J, Tinelli C, Lisziewicz J: Control of SIV rebound through structured treatment interruptions during early infection. Science 2000, 290(5496):1591-1593.

19. Lori F, Lisziewicz J: Rationale for the use of hydroxyurea as an anti-human immunodeficiency virus drug. Clin Infect Dis 2000, 30(Suppl 2):S193-S197. Review.

20. Longhurst HJ, Pinching AJ: Drug points: pancreatitis associated with hydroxyurea in combination with didanosine. BMJ 2001, 322(7278):81.

21. Weissman SB, Sinclair Gl, Green CL, Fissell WH: Hydroxyurea-induced hepatitis in human immunodeficiency virus-positive patients. Clin Infect Dis 1999, 29(1):223-224. 
22. Lori F, De Forni D, Katabira E, Baev D, Maserati R, Calarota SA, Cahn P, Testori M, Rakhmanova A, Stevens MR: VS411 reduced immune activation and HIV-1 RNA levels in 28 days: randomized proof-of-concept study for antiviral-hyperactivation limiting therapeutics. PLoS One 2012, 7(10): e47485. doi: 10.1371/journal.pone.0047485.

23. Van Rompay KK, Trott KA, Jayashankar K, Geng Y, LaBranche CC, Johnson JA, Landucci G, Lipscomb J, Tarara RP, Canfield DR, Heneine W, Forthal DN, Montefiori D, Abel K: Prolonged tenofovir treatment of macaques infected with $\mathrm{K} 65 \mathrm{R}$ reverse transcriptase mutants of SIV results in the development of antiviral immune responses that control virus replication after drug withdrawal. Retrovirology 2012, 9:57. doi: 10.1186/1742-4690-9-57.

24. Rosenberg ES, Altfeld M, Poon SH, Phillips MN, Wilkes BM, Eldridge RL, Robbins GK, D'Aquila RT, Goulder PJ, Walker BD: Immune control of HIV-1 after early treatment of acute infection. Nature 2000, 407(6803):523-526.

25. Lampe FC, Porter K, Kaldor J, Law M, Kinloch-de Loes S, Phillips AN, CASCADE Collaboration: Effect of transient antiretroviral treatment during acute HIV infection: comparison of the quest trial results with CASCADE natural history study. Antivir Ther 2007, 12(2):189-193.

26. Volberding P, Demeter $L$, Bosch RJ, Aga E, Pettinelli C, Hirsch M, Vogler M, Martinez A, Little S, Connick E, ACTG 371 Team: Antiretroviral therapy in acute and recent HIV infection: a prospective multicenter stratified trial of intentionally interrupted treatment. AIDS 2009, 23(15):1987-1995. doi: 10.1097/QAD.0b013e32832eb285.

27. Hocqueloux L, Prazuck T, Avettand-Fenoel V, Lafeuillade A, Cardon B, Viard $J P$, Rouzioux C: Long-term immunovirologic control following antiretroviral therapy interruption in patients treated at the time of primary HIV1 infection. AIDS 2010, 24(10):1598-1601.

28. Lodi S, Meyer L, Kelleher AD, Rosinska M, Ghosn J, Sannes M, Porter K: Immunovirologic control 24 months after interruption of antiretroviral therapy initiated close to HIV seroconversion. Arch Intern Med 2012, 172(16):1252-1255. doi: 10.1001/archinternmed.2012.2719.

29. Sáez-Cirión A, Bacchus C, Hocqueloux L, Avettand-Fenoel V, Girault I, Lecuroux C, Potard V, Versmisse P, Melard A, Prazuck T, Descours B, Guergnon J, Viard JP, Boufassa F, Lambotte O, Goujard C, Meyer L, Costagliola D, Venet A, Pancino G, Autran B, Rouzioux C: Post-treatment HIV-1 controllers with a long-term virological remission after the interruption of early initiated antiretroviral therapy ANRS VISCONTI Study. PLOS Pathog 2013, 9(3):e1003211. doi: 10.1371/journal.ppat.1003211.

30. Persaud D, Gay H, Ziemniak C, Chen YH, Piatak M Jr, Chun TW, Strain M, Richman D, Luzuriaga K: Absence of detectable HIV-1 viremia after treatment cessation in an infant. N Engl J Med 2013, 369(19):1828-1835. doi: 10.1056/NEJMoa1302976

31. Desquilbet L, Goujard C, Rouzioux C, Sinet M, Deveau C, Chaix ML, Séréni D, Boufassa F, Delfraissy JF, Meyer L, PRIMO and SEROCO Study Groups: Does transient HAART during primary HIV-1 infection lower the virological setpoint? AIDS 2004, 18(18):2361-2369.

32. Streeck $H$, Jessen $H$, Alter $G$, Teigen $N$, Waring MT, Jessen A, Stahmer I, van Lunzen J, Lichterfeld M, Gao X, Allen TM, Carrington M, Walker BD, Rockstroh JK, Altfeld M: Immunological and virological impact of highly active antiretroviral therapy initiated during acute HIV-1 infection. J Infect Dis 2006, 194(6):734-739.

33. Pantazis N, Touloumi G, Vanhems P, Gill J, Bucher HC, Porter K, CASCADE Collaboration: The effect of antiretroviral treatment of different durations in primary HIV infection. AIDS 2008, 22(18):2441-2450. doi: 10.1097/ QAD.0b013e328319ea4e.

34. Oxenius A, Price DA, Easterbrook PJ, O'Callaghan CA, Kelleher AD, Whelan JA, Sontag G, Sewell AK, Phillips RE: Early highly active antiretroviral therapy for acute HIV-1 infection preserves immune function of CD8+ and CD4+ T lymphocytes. Proc Natl Acad Sci U S A 2000, 97(7):3382-3387.

35. Moir S, Buckner CM, Ho J, Wang W, Chen J, Waldner AJ, Posada JG, Kardava L, O'Shea MA, Kottilil S, Chun TW, Proschan MA, Fauci AS: B cells in early and chronic HIV infection: evidence for preservation of immune function associated with early initiation of antiretroviral therapy. Blood 2010, 116(25):5571-5579. doi: 10.1182/blood-2010-05-285528.

36. Ngo-Giang-Huong N, Deveau C, Da Silva I, Pellegrin I, Venet A, Harzic M, Sinet M, Delfraissy JF, Meyer L, Goujard C, Rouzioux C, French PRIMO Cohort Study Group: Proviral HIV-1 DNA in subjects followed since primary HIV-1 infection who suppress plasma viral load after one year of highly active antiretroviral therapy. AIDS 2001, 15(6):665-673.
37. Archin NM, Vaidya NK, Kuruc JD, Liberty AL, Wiegand A, Kearney MF, Cohen MS, Coffin JM, Bosch RJ, Gay CL, Eron JJ, Margolis DM, Perelson AS: Immediate antiviral therapy appears to restrict resting $\mathrm{CD}^{+}$cell HIV- 1 infection without accelerating the decay of latent infection. Proc Natl Acad Sci U S A 2012, 109(24):9523-9528. doi: 10.1073/pnas.1120248109.

38. Jain V, Hartogensis W, Bacchetti P, Hunt PW, Hatano H, Sinclair E, Epling L, Lee TH, Busch MP, McCune JM, Pilcher CD, Hecht FM, Deeks SG: Antiretroviral therapy initiated within Six months of HIV infection is associated with lower T-cell activation and smaller HIV reservoir size. J Infect Dis 2013, 208(8):1202-1211. doi: 10.1093/infdis/jit311.

39. Chun TW, Justement JS, Murray D, Hallahan CW, Maenza J, Collier AC, Sheth PM, Kaul R, Ostrowski M, Moir S, Kovacs C, Fauci AS: Rebound of plasma viremia following cessation of antiretroviral therapy despite profoundly low levels of HIV reservoir: implications for eradication. AIDS 2010, 24(18):2803-2808. doi: 10.1097/QAD.0b013e328340a239.

40. Dybul M, Nies-Kraske E, Daucher M, Hertogs K, Hallahan CW, Csako G, Yoder C, Ehler L, Sklar PA, Belson M, Hidalgo B, Metcalf JA, Davey RT, Rock Kress DM, Powers A, Fauci AS: Long-cycle structured intermittent versus continuous highly active antiretroviral therapy for the treatment of chronic infection with human immunodeficiency virus: effects on drug toxicity and on immunologic and virologic parameters. J Infect Dis 2003, 188(3):388-396.

41. Alexander TH, Ortiz GM, Wellons MF, Allen A, Grace EJ 2nd, Schweighardt B, Brancato J, Sandberg JK, Furlan SN, Miralles GD, Nixon DF, Bartlett JA: Changes in $\mathrm{CD}^{+}$T-cell differentiation phenotype during structured treatment interruption in patients with chronic HIV-1 infection. J Acquir Immune Defic Syndr 2003, 34(5):475-481.

42. Papasavvas E, Kostman JR, Mounzer K, Grant RM, Gross R, Gallo C, Azzoni L, Foulkes A, Thiel B, Pistilli M, Mackiewicz A, Shull J, Montaner LJ: Randomized, controlled trial of therapy interruption in chronic HIV-1 infection. PLoS Med 2004, 1(3):e64.

43. Pai NP, Tulsky JP, Lawrence J, Colford JM Jr, Reingold AL: Structured treatment interruptions (STI) in chronic suppressed HIV infection in adults. Cochrane Database Syst Rev 2005, 2005(4):CD005482. Review.

44. Hamer DH: Can HIV, be cured? Mechanisms of HIV persistence and strategies to combat it. Curr HIV Res 2004, 2(2):99-111. Review.

45. Van Lint C, Bouchat S, Marcello A: HIV-1 transcription and latency: an update. Retrovirology 2013, 10:67. doi: 10.1186/1742-4690-10-67. Review.

46. Sgarbanti $M$, Battistini $A$ : Therapeutics for HIV-1 reactivation from latency. Curr Opin Virol 2013, 3(4):394-401. doi: 10.1016/j.coviro.2013.06.001. Review.

47. Wightman F, Ellenberg $P$, Churchill M, Lewin SR: HDAC inhibitors in HIV. Immunol Cell Biol 2012, 90(1):47-54. doi: 10.1038/icb.2011.95. Review.

48. Archin NM, Liberty AL, Kashuba AD, Choudhary SK, Kuruc JD, Crooks AM Parker DC, Anderson EM, Kearney MF, Strain MC, Richman DD, Hudgens MG, Bosch RJ, Coffin JM, Eron JJ, Hazuda DJ, Margolis DM: Administration of vorinostat disrupts HIV-1 latency in patients on antiretroviral therapy. Nature 2012, 487(7408):482-485. doi: 10.1038/nature11286. Erratum in: Nature. 2012; 489(7416):460.

49. Elliott J, Solomon A, Wightman F, Smith M, Palmer S, Prince M, Watson J, Hoy J, McMahon J, Lewin SR: The safety and effect of multiple doses of vorinostat on HIV transcription in HIV + patients receiving cART. In 20th Conference on Retroviruses and Opportunistic Infections (CROI). Atlanta, USA: Oral late breaker; 2013. abstract LB50.

50. Monforte AD, Svicher V, Nozza S, Lazzarin A, Marchetti G, Perno CF: Highlights on HIV eradication in 2013. AIDS 2013 [Epub ahead of print]

51. Lifson J, Del Prete G, Kiser R, Trubey CM, Smedley J, Coalter V, Oswald K, Shoemaker R, Fast R, Li Y, Lara A, Wiles A, Wiles R, Macallister R, Sanchez R, Wai J, Tan C, Keele B, Estes J, Piatak M Jr, Hazuda DJ: Evaluation of treatment with the histone deacetylase inhibitor vorinostat (suberoylanilide hydroxamic acid; SAHA) in antiretroviral drug treated, SIVmac239-infected Rhesus Macaques. In Towards a Cure: IAS preconference symposium. Washington D.C.: Oral presentation; 2012

52. Lewis MG, DaFonseca S, Chomont N, Palamara AT, Tardugno M, Mai A, Collins M, Wagner WL, Yalley-Ogunro J, Greenhouse J, Chirullo B, Norelli $S$, Garaci E, Savarino A: Gold drug auranofin restricts the viral reservoir in the monkey AIDS model and induces containment of viral load following ART suspension. AIDS 2011, 25(11):1347-1356. doi: 10.1097/ QAD.0b013e328347bd77.

53. Savarino A, Mai A, Norelli S, El Daker S, Valente S, Rotili D, Altucci L, Palamara AT, Garaci E: "Shock and kill" effects of class I-selective histone deacetylase inhibitors in combination with the glutathione synthesis 
inhibitor buthionine sulfoximine in cell line models for HIV-1 quiescence. Retrovirology 2009, 6:52. doi: 10.1186/1742-4690-6-52.

54. Rasmussen TA, Schmeltz Søgaard O, Brinkmann C, Wightman F, Lewin SR, Melchjorsen J, Dinarello C, Ostergaard L, Tolstrup M: Comparison of HDAC inhibitors in clinical development: effect on HIV production in latently infected cells and T-cell activation. Hum Vaccin Immunother 2013, 9(5):993-1001. doi: 10.4161/hv.23800.

55. Shan L, Xing S, Yang HC, Zhang H, Margolick JB, Siliciano RF: Unique characteristics of histone deacetylase inhibitors in reactivation of latent HIV-1 in Bcl-2-transduced primary resting CD4+ T cells. J Antimicrob Chemother 2013 [Epub ahead of print].

56. Vandergeeten $\mathrm{C}$, Fromentin $\mathrm{R}$, Chomont $\mathrm{N}$ : The role of cytokines in the establishment, persistence and eradication of the HIV reservoir. Cytokine Growth Factor Rev 2012, 23(4-5):143-149. doi: 10.1016/j. cytogfr.2012.05.001. Review.

57. Imamichi H, Degray G, Asmuth DM, Fischl MA, Landay AL, Lederman MM, Sereti I: HIV-1 viruses detected during episodic blips following interleukin-7 administration are similar to the viruses present before and after interleukin-7 therapy. AIDS 2011, 25(2):159-164. doi: 10.1097/ QAD.0b013e328340a270.

58. Vandergeeten C, Fromentin R, DaFonseca S, Lawani MB, Sereti I, Lederman MM, Ramgopal M, Routy JP, Sékaly RP, Chomont N: Interleukin-7 promotes HIV persistence during antiretroviral therapy. Blood 2013,

121(21):4321-4329. doi: 10.1182/blood-2012-11-465625.

59. Bosque A, Famiglietti M, Weyrich AS, Goulston C, Planelles V: Homeostatic proliferation fails to efficiently reactivate HIV-1 latently infected central memory CD4 ${ }^{+}$T cells. PLoS Pathog 2011, 7(10):e1002288. doi: 10.1371/ journal.ppat.1002288

60. Hütter G, Nowak D, Mossner M, Ganepola S, Müssig A, Allers K, Schneider T, Hofmann J, Kücherer C, Blau O, Blau IW, Hofmann WK, Thiel E: Long-term control of HIV by CCR5 Delta32/Delta32 stem-cell transplantation. $N$ Engl J Med 2009, 360(7):692-698. doi: 10.1056/NEJMoa0802905.

61. Allers K, Hütter G, Hofmann J, Loddenkemper C, Rieger K, Thiel E, Schneider T: Evidence for the cure of HIV infection by CCR5 $\Delta 32 / \Delta 32$ stem cell transplantation. Blood 2011, 117(10):2791-2799. doi: 10.1182/blood-201009-309591.

62. Dean M, Carrington M, Winkler C, Huttley GA, Smith MW, Allikmets R, Goedert J, Buchbinder SP, Vittinghoff E, Gomperts E, Donfield S, Vlahov D, Kaslow R, Saah A, Rinaldo C, Detels R, O'Brien SJ: Genetic restriction of HIV-1 infection and progression to AIDS by a deletion allele of the CKR5 structural gene. Hemophilia Growth and Development Study, Multicenter AIDS Cohort Study, Multicenter Hemophilia Cohort Study, San Francisco City Cohort, ALIVE Study. Science. 1996, 273(5283):1856-62. Erratum in: Science 1996; 274 (5290):1069.

63. Yukl SA, Boritz E, Busch M, Bentsen C, Chun TW, Douek D, Eisele E, Haase A, Ho YC, Hütter G, Justement JS, Keating S, Lee TH, Li P, Murray D, Palmer S, Pilcher C, Pillai S, Price RW, Rothenberger M, Schacker T, Siliciano J, Siliciano R, Sinclair E, Strain M, Wong J, Richman D, Deeks SG: Challenges in detecting HIV persistence during potentially curative interventions: a study of the Berlin patient. PLoS Pathog 2013, 9(5):e1003347. doi: 10.1371/ journal.ppat.1003347.

64. Hütter G, Zaia JA: Allogeneic haematopoietic stem cell transplantation in patients with human immunodeficiency virus: the experiences of more than 25 years. Clin Exp Immunol 2011, 163(3):284-295. doi: 10.1111/j.13652249.2010.04312.x. Review.

65. Huzicka I: Could bone marrow transplantation cure AIDS?: review. Med Hypotheses 1999, 52(3):247-257.

66. Ando D, Lalezari J, Blick G, Rodriquez J, Hsu R, Hawkins T, Parks D, Zeidan J, Sekaly RP, Deeks S: Functional control of viremia in CCR5- $\triangle 32$ heterozygous $(\triangle 32 \mathrm{HZ}) \mathrm{HIV}^{+}$subjects following adoptive transfer of zinc finger nuclease CCR5 modified autologous CD4 T-cells (SB-728-T). In 53rd Interscience Conference on Antimicrobial Agents and Chemotherapy (ICAAC). Denver, USA; 2013.

67. Lee GK, Zeidan J, Lalezari J, Mitsuyasu R, Wang S, Giedlin M, Nichol G, Tang W, Ando D, Sekaly RP: Long Term CD4 Reconstitution in HIV Subjects Receiving ZFN CCR5 Modified CD4 T-Cells (SB-728-T) May Be Attributed to the Sustained Durability of the Central Memory T-Cell Subset. In 20th Conference on Retroviruses and Opportunistic Infections (CROI). Atlanta, USA; 2013. Abstract \#126.

68. Henrich TJ, Hu Z, Li JZ, Sciaranghella G, Busch MP, Keating SM, Gallien S, Lin $\mathrm{NH}$, Giguel FF, Lavoie L, Ho VT, Armand P, Soiffer RJ, Sagar M, Lacasce AS,
Kuritzkes DR: Long-term reduction in peripheral blood HIV type 1 reservoirs following reduced-intensity conditioning allogeneic stem cell transplantation. J Infect Dis 2013, 207(11):1694-1702. doi: 10.1093/infdis/jit086.

69. Henrich T, Hanhauser E, Sirignano M, Davis B, Lee TH, Keating S, Busch M, Marty F, LaCasce A, Armand P, Soiffer R, Altfeld M, Kuritzkes D: In depth investigation of peripheral and gut HIV-1 reservoirs, HIV-specific cellular immunity, and host microchimerism following allogeneic hematopoetic stem cell transplantation. In 7th IAS Conference on HIV Pathogenesis, Treatment and Prevention. Kuala Lumpur, Malaysia; 2013. Abstract WELBA05.

70. Stewart GJ, Ashton LJ, Biti RA, Ffrench RA, Bennetts BH, Newcombe NR, Benson EM, Carr A, Cooper DA, Kaldor JM: Increased frequency of CCR-5 delta 32 heterozygotes among long-term non-progressors with HIV-1 infection. The Australian long-term Non-progressor study group. AIDS 1997, 11(15):1833-1838.

71. Paiardini M, Cervasi B, Reyes-Aviles E, Micci L, Ortiz AM, Chahroudi A, Vinton C, Gordon SN, Bosinger SE, Francella N, Hallberg PL, Cramer E, Schlub T, Chan ML, Riddick NE, Collman RG, Apetrei C, Pandrea I, Else J, Munch J, Kirchhoff F, Davenport MP, Brenchley JM, Silvestri G: Low levels of SIV infection in sooty mangabey central memory $\mathrm{CD} 4^{+} \mathrm{T}$ cells are associated with limited CCR5 expression. Nat Med 2011, 17(7):830-836. doi: 10.1038/nm.2395.

72. Jeng RR, van den Brink MR: Allogeneic haematopoietic stem cell transplantation: individualized stem cell and immune therapy of cancer. Nat Rev Cancer 2010, 10(3):213-221. doi: 10.1038/nrc2825. Review. Erratum in: Nat Rev Cancer. 2010;10(3).

73. Suarez-Almazor ME, Spooner CH, Belseck E, Shea B: Auranofin versus placebo in rheumatoid arthritis. Cochrane Database Syst Rev 2000, 2000(2): CD002048. Review.

74. Shytaj IL, Norelli S, Chirullo B, Della Corte A, Collins M, Yalley-Ogunro J, Greenhouse J, Iraci N, Acosta EP, Barreca ML, Lewis MG, Savarino A: A highly intensified ART regimen induces long-term viral suppression and restriction of the viral reservoir in a simian AIDS model. PLoS Pathog 2012, 8(6):e1002774. doi: 10.1371/journal.ppat.1002774.

75. Vanham G, Van Gulck E: Can immunotherapy be useful as a "functional cure" for infection with Human Immunodeficiency Virus-1? Retrovirology 2012, 9:72. doi: 10.1186/1742-4690-9-72. Review.

76. Betts MR, Nason MC, West SM, De Rosa SC, Migueles SA, Abraham J, Lederman MM, Benito JM, Goepfert PA, Connors M, Roederer M, Koup RA: HIV nonprogressors preferentially maintain highly functional HIV-specific CD8 ${ }^{+}$T cells. Blood 2006, 107(12):4781-4789.

77. Almeida JR, Price DA, Papagno L, Arkoub ZA, Sauce D, Bornstein E, Asher TE, Samri A, Schnuriger A, Theodorou I, Costagliola D, Rouzioux C, Agut $H$, Marcelin AG, Douek D, Autran B, Appay V: Superior control of HIV-1 replication by $\mathrm{CD} 8^{+} \mathrm{T}$ cells is reflected by their avidity, polyfunctionality, and clonal turnover. J Exp Med 2007, 204(10):2473-2485.

78. Hersperger AR, Pereyra F, Nason M, Demers K, Sheth P, Shin LY, Kovacs CM, Rodriguez B, Sieg SF, Teixeira-Johnson L, Gudonis D, Goepfert PA, Lederman MM, Frank I, Makedonas G, Kaul R, Walker BD, Betts MR: Perforin expression directly ex vivo by HIV-specific CD8 T-cells is a correlate of HIV elite control. PLOS Pathog 2010, 6(5):e1000917. doi: 10.1371/journal.ppat.1000917.

79. Buckheit RW 3rd, Siliciano RF, Blankson JN: Primary $\mathrm{CD} 8^{+} \mathrm{T}$ cells from elite suppressors effectively eliminate non-productively HIV-1 infected resting and activated CD4 ${ }^{+}$T cells. Retrovirology 2013, 10:68. doi: 10.1186/1742-4690-10-68.

80. Bailey HH, Ripple G, Tutsch KD, Arzoomanian RZ, Alberti D, Feierabend C, Mahvi D, Schink J, Pomplun M, Mulcahy RT, Wilding G: Phase I study of continuous-infusion L-S, R-buthionine sulfoximine with intravenous melphalan. J Natl Cancer Inst 1997, 89(23):1789-1796.

81. Shytaj IL, Chirullo B, Wagner W, Ferrari MG, Sgarbanti R, Corte AD, LaBranche C, Lopalco L, Palamara AT, Montefiori D, Lewis MG, Garaci E, Savarino A: Investigational treatment suspension and enhanced cell-mediated immunity at rebound followed by drug-free remission of simian AIDS. Retrovirology 2013, 10:71. doi: 10.1186/1742-4690-10-71.

82. Stephenson KE, Li H, Walker BD, Michael NL, Barouch DH: Gag-specific cellular immunity determines in vitro viral inhibition and in vivo virologic control following simian immunodeficiency virus challenges of vaccinated rhesus monkeys. J Virol 2012, 86(18):9583-9589. doi: 10.1128/ JVI.00996-12.

83. Edwards BH, Bansal A, Sabbaj S, Bakari J, Mulligan MJ, Goepfert PA: Magnitude of functional $C D 8^{+} \mathrm{T}$-cell responses to the gag protein of human immunodeficiency virus type 1 correlates inversely with viral load in plasma. J Virol 2002, 76(5):2298-2305. 
84. Zuñiga R, Lucchetti A, Galvan P, Sanchez S, Sanchez C, Hernandez A, Sanchez $H$, Frahm N, Linde CH, Hewitt HS, Hildebrand W, Altfeld M, Allen TM, Walker BD, Korber BT, Leitner T, Sanchez J, Brander C: Relative dominance of Gag p24-specific cytotoxic T lymphocytes is associated with human immunodeficiency virus control. J Virol 2006, 80(6):3122-3125.

85. Kiepiela P, Ngumbela K, Thobakgale C, Ramduth D, Honeyborne I, Moodley E, Reddy S, de Pierres C, Mncube Z, Mkhwanazi N, Bishop K, van der Stok M, Nair K, Khan N, Crawford H, Payne R, Leslie A, Prado J, Prendergast A, Frater J, McCarthy N, Brander C, Learn GH, Nickle D, Rousseau C, Coovadia $H$, Mullins Jl, Heckerman D, Walker BD, Goulder P: CD8 ${ }^{+}$T-cell responses to different HIV proteins have discordant associations with viral load. Nat Med 2007, 13(1):46-53.

86. Julg B, Williams KL, Reddy S, Bishop K, Qi Y, Carrington M, Goulder PJ, Ndung'U T, Walker BD: Enhanced anti-HIV functional activity associated with Gag-specific CD8 T-cell responses. J Virol 2010, 84(11):5540-5549. doi: 10.1128/JVI.02031-09.

87. Pace MJ, Graf EH, Agosto LM, Mexas AM, Male F, Brady T, Bushman FD, O'Doherty U: Directly infected resting CD4 ${ }^{+} \mathrm{T}$ cells can produce HIV Gag without spreading infection in a model of HIV latency. PLOS Pathog 2012, 8(7):e1002818. doi: 10.1371/journal.ppat.1002818.

88. Lu W, Wu X, Lu Y, Guo W, Andrieu JM: Therapeutic dendritic-cell vaccine for simian AIDS. Nat Med 2003, 9(1):27-32.

89. Lu W, Arraes LC, Ferreira WT, Andrieu JM: Therapeutic dendritic-cell vaccine for chronic HIV-1 infection. Nat Med 2004, 10(12):1359-1365.

90. García F, Climent N, Assoumou L, Gil C, González N, Alcamí J, León A, Romeu J, Dalmau J, Martínez-Picado J, Lifson J, Autran B, Costagliola D, Clotet B, Gatell JM, Plana M, Gallart T, DCV2/MANONO7- AIDS Vaccine Research Objective Study Group: A therapeutic dendritic cell-based vaccine for HIV-1 infection. J Infect Dis 2011, 203(4):473-478.

91. García F, Climent N, Guardo AC, Gil C, León A, Autran B, Lifson JD, MartínezPicado J, Dalmau J, Clotet B, Gatell JM, Plana M, Gallart T, DCV2/MANON07ORVACS Study Group: A dendritic cell-based vaccine elicits T cell responses associated with control of HIV-1 replication. Sci Transl Med 2013, 5(166):166ra2. doi: 10.1126/scitranslmed.3004682.

92. Hansen SG MP Jr, Ventura AB, Hughes CM, Gilbride RM, Ford JC, Oswald K Shoemaker R, Li Y, Lewis MS, Gilliam AN, Xu G, Whizin N, Burwitz BJ, Planer SL, Turner JM, Legasse AW, Axthelm MK, Nelson JA, Früh K, Sacha JB, Estes JD, Keele BF, Edlefsen PT, Lifson JD, Picker LJ: Immune clearance of highly pathogenic SIV infection. Nature 2013, 502(7469):100-104. doi: 10.1038/ nature12519.

93. Hansen SG, Ford JC, Lewis MS, Ventura AB, Hughes CM, Coyne-Johnson L Whizin N, Oswald K, Shoemaker R, Swanson T, Legasse AW, Chiuchiolo MJ, Parks CL, Axthelm MK, Nelson JA, Jarvis MA, Piatak M Jr, Lifson JD, Picker L Profound early control of highly pathogenic SIV by an effector memory T-cell vaccine. Nature 2011, 473(7348):523-527. doi: 10.1038/nature10003.

94. Vagenas P, Aravantinou M, Williams VG, Jasny E, Piatak M Jr, Lifson JD, Salazar AM, Blanchard JL, Gettie A, Robbiani M: A tonsillar PolyICLC/AT-2 SIV therapeutic vaccine maintains low viremia following antiretroviral therapy cessation. PLoS One 2010, 5(9):e12891. doi: 10.1371/journal.pone.0012891.

95. Barouch DH, Whitney JB, Moldt B, Klein F, Oliveira TY, Liu J, Stephenson KE, Chang HW, Shekhar K, Gupta S, Nkolola JP, Seaman MS, Smith KM, Borducchi EN, Cabral C, Smith JY, Blackmore S, Sanisetty S, Perry JR, Beck M, Lewis MG, Rinaldi W, Chakraborty AK, Poignard P, Nussenzweig MC, Burton DR: Therapeutic efficacy of potent neutralizing HIV-1-specific monoclonal antibodies in SHIV-infected rhesus monkeys. Nature 2013. doi: 10.1038/ nature12744. [Epub ahead of print].

96. Villinger F, Brice GT, Mayne AE, Bostik P, Mori K, June CH, Ansari AA: Adoptive transfer of simian immunodeficiency virus (SIV) naïve autologous CD4(+) cells to macaques chronically infected with SIV is sufficient to induce long-term nonprogressor status. Blood 2002, 99(2):590-599.

97. Cillo AR, Krishnan A, Mitsuyasu RT, McMahon DK, Li S, Rossi JJ, Zaia JA, Mellors JW: Plasma viremia and cellular HIV-1 DNA persist despite autologous hematopoietic stem cell transplantation for HIV-related lymphoma. J Acquir Immune Defic Syndr 2013, 63(4):438-441. doi: 10.1097/ QAl.0b013e31828e6163.

doi:10.1186/1742-4690-10-145

Cite this article as: Shytaj and Savarino: A cure for AIDS: a matter of timing?. Retrovirology 2013 10:145.

\section{Submit your next manuscript to BioMed Central and take full advantage of:}

- Convenient online submission

- Thorough peer review

- No space constraints or color figure charges

- Immediate publication on acceptance

- Inclusion in PubMed, CAS, Scopus and Google Scholar

- Research which is freely available for redistribution

Submit your manuscript at www.biomedcentral.com/submit
C BioMed Central 